\title{
Information Literacy in Serbia: Initiatives and Strategies
}

\author{
Gordana Stokić Simončić ${ }^{1}$, Željko Vučković \\ ${ }^{1}$ Library and Information Science Department, Faculty of Philology, Belgrade University, \\ Studentski trg 3, Belgrade 11000, Republic of Serbia, \\ gordana.stokic@yahoo.com \\ ${ }^{2}$ Faculty of Pedagogy, Novi Sad University, \\ Podgoricka 4, Sombor 25000, Republic of Serbia, \\ z.vuckovic@yahoo.com
}

\begin{abstract}
The general aspiration towards joining the European Union and creating the knowledge society in Serbia involve significant challenges for the Country. One of the most demanding changes that Serbian libraries will be facing consists of implementing information literacy (IL), i.e. citizens that are prepared for lifelong learning in a world that is overloaded with information of all sorts. The essential premise of this paper lies with two convictions of the authors: that, on the one hand, libraries are a natural environment for the development of information literacy, and on the other, information literacy must contribute to the citizens' quality of living. The paper will offer a general overview of the current status of IL in Serbia, the actors in the IL process, the programs, the initiatives, and, above all, what the role of libraries in this endeavor is.
\end{abstract}

Key words: Information literacy, knowledge society, library’s mission, libraries in Serbia, information literacy in Serbia

\section{Introduction}

Many dilemmas and misunderstandings follow the idea and practice of information literacy which we could justly describe as myths of information literacy. The most widespread include: 1) information literacy is predominantly a technological, not a social or educational phenomenon, 2) information literacy develops on its own, with the spread of information and communications technologies in everyday life, 3 ) information literacy matters only in formal educational institutions, i.e. school system, and 4) there is a fundamental, qualitative difference between traditional education of users in libraries and information literacy.

On the other pole of these myths stand the authors that justly appeal to the fact that the matter of information literacy is neither easy nor simple, pointing to the numerous paradoxes and aporias of information society. We wallow in information, yet we crave true knowledge. The more new information and communications means are, the less time we spend for speaking to one another and less true communication and sociability we achieve. Contemporary man reads and does research less and less, receiving fulfilment from trivial media and information resources, floating on the surface of things, neglecting the attitude of a researcher and critic of the society in which he lives. Virtual reality appears as a surrogate of real life. In a context like this, libraries must restore their own responsibility and find their place in the information vicious circle.

In Serbia, where the Internet took roots in 1996, which invests slightly over 62 Euro per capita in the development of information technology and in which fewer than two per mill of inhabitants have an ECDL permit, the dilemmas related to information literacy also increase with the uneven development of certain regions, difficulties in restructuring the productive and service sectors, and the slow legal regulation of the still budding and underdeveloped information sector.

This paper will review the basic problems related to the adoption of the information literacy concept in Serbia, and the implications of those issues to Serbian libraries. The essential premise of this paper lies in two convictions of the authors: that, on the one hand, libraries are a natural environment for the development of information literacy, and on the other, information literacy must contribute to the improvement in citizens' standard of living.

\section{Information Literacy and Libraries}

Knowledge society as the emerging social paradigm has established a new model of relations, new concept of the organisation, 
different system of values, need for an educational reform and another view of what an educated person is, alongside with the expanded concept of literacy. Traditional or elementary literacy, which includes the ability to read, write and perform basic mathematical operations, has been proven inadequate for orientation in the information and knowledge society. The new, expanded concept of literacy encompasses a set of skills such as computer literacy, media literacy, digital literacy and information literacy. We shall give a brief survey of each of the listed skills, with special emphasis on the concept of information literacy and its relation to contemporary librarianship.

Computer literacy is defined as the ability to use computer systems, networks and programmes. Although this skill is often identified with information literacy, these are two distinct phenomena: computer literacy primarily comprises the knowledge of technology and its functioning, whereas information literacy rather deals with the contents, quality and relevance of information sources. In order for a person to be information literate, he/she has to possess elementary computer knowledge. However, computer literacy does not imply information literacy as well: a person may be technologically educated and competent, and yet need help regarding the quality of retrieved information.

Media literacy includes the ability to understand, use, analyse and interpret messages in all mass media forms newspapers, magazines, the radio, television and the internet. Media literacy stimulates people to think critically and understand the media messages expressed in image, sound and language.

Digital literacy implies the ability to use and understand hypertext and multimedia content. Digital literacy also refers to information available on the internet, but to all digitised material and cultural heritage available in the form of multimedia presentation.

We can conclude that literacy in the $21^{\text {st }}$ century comprises a complex of new and intertwined skills and abilities. Nevertheless, it is only information literacy that opens up the path to selecting relevant information and knowledge from the torrent of data that overwhelms us in the world of modern media and technologies.

The term information literacy was first used by the US informatician Paul Zurowski in 1974, defining this concept as an efficient use of information in problem solving, and in 1989 the American Library Association formulated today's widely accepted definition according to which those persons are information literate who have learned how they should learn, because they know how human knowledge is organised, how to find the right information and how to use it efficiently. Information literacy qualifies people for lifelong learning and for being successful in the dynamic surroundings of highly developed information technologies. Various definitions of information literacy have several elements in common: the ability to efficiently search through information, information selection and assessment, the use of a broad spectrum of communications technologies, the consciousness of the problem of information reliability and authenticity, the efficient information transmission to other people.

The development of the information literacy concept has its technological, but also its social and ethical aspects. It seemed that technology, especially the development of the internet, would solve the education crisis resulting from the conflict of traditional pedagogic principles and demands of the information age, and thus open up a perspective of knowledge and learning society.

The well-known UNESCO document Learning: the Treasure Within, published in 1994 under the editorship of Jacques Delors, points to the fact that information technology facilitates quick data access, but that, for the process of its utilisation, it is necessary to know the processes of collection, selection, organisation and assessment of information. The mentioned UNESCO study deals with the "digital divide", i.e. the increasingly wider gap between informationally rich and poor countries. This divide does not exist only between various states, but also between individuals who know how to use new information and communications technologies and those that have not mastered these skills yet. Therefore, both schools and libraries bear the special responsibility to 
enable every individual to face the abundance of information and to express their critical and creative spirit in selecting, ranking and using information resources. There are some authors who define information literacy not only as a prerequisite for lifelong learning, but also as one of the fundamental human rights in the $21^{\text {st }}$-century global society.

Seen from the sociological and philosophical points of view, the realisation of the information literacy concept can be understood as the reaffirmation of the Enlightenment idea of the indissoluble relation of knowledge, human liberty and democracy. More than two hundred years ago, Condorcet in his Sketch for a Historical Picture of the Progress of the Human Mind laid out the idea of mankind's constant progress on the basis of knowledge and education. Condorcet explains the Enlightenment doctrine that the spreading of science and education to every individual will result in the abolition of all inequalities between nations and produce a true perfection of the human kind. The spread of information and knowledge through the advancement and democratisation of education will have a decisive role in establishing the political liberties and human happiness. Therefore even now should we approach the information literacy concept not only as a technological ability, but also as a sort of instrument of human liberty and equality and as the skill to critically assess the intellectual, human and social potentials and limitations of information resources and technologies.

The promptness and readiness of libraries to adapt their goals to technological and social changes now and in the future will stand as a measure of their vitality, social status and influence. Among the new goals the libraries have to include the development and promotion of information literacy both among librarians themselves and in the whole community of users. Information literacy in libraries demands an active and committed approach to users that has two essential innovative aspects: the transformation from an objective-based approach to actual problems of users and encouragement of their independent research, and the emphasis on the need of lifelong and creative learning.
Nowadays we witness a new change in the dominant functions of libraries. The key importance is assigned to the information analysis that pervades all library processes. Viewed historically, this function also existed in the first libraries, when the analysis of documents appeared for the purpose of classifying and systematising them. A systematised order of documents is the prerequisite of housing and accessing the collections. In time, the information analysis function has developed and become more complex both formally and essentially, having come the long way from collection arrangement to intricate referencebibliographic methods and the building of new information systems. In an electronic environment, the information analysis function assumes new forms and content. In the world's large libraries special services are formed for semantic information processing, which approach information processing from the level of their sense and meaning. Their task is to study the content, not just the form of published knowledge.

If we accept the claim that information analysis now is the new dominant function of library work, it is accompanied at the social function level by the axiological orientation function in the information universe. This relation has become increasingly important since the advent of the internet, when we feel the express necessity of a stricter organisation of the very disorganised global information infrastructure. Librarians as a professional group that naturally pursues classification, systematisation and organisation of documents, also have the obligation and chance to contribute to solving the problem of systematisation and assessment of electronic publications as a future form of scientific, and everyday communication as well.

The future of librarianship is related to the conception and practice of virtual library, imagined as the entirety of information resources available to the user through global computer networks. Therefore the functions and information analysis and assessment, and of navigation and orientation in the new information reality are essential to all the types of libraries, both for scientific and increasingly for public libraries. In information society the library becomes an institution that, besides the classic carriers of 
recorded knowledge and experience, must pay more attention to collecting, processing, organising, preserving, protecting and using electronic resources. To these traditionally librarian functions, regardless of the technological environment, we should also add the task of content processing, assessment and qualitative selection of electronic publications. Although the last task is not completely new to the librarians either, it assumes a special importance in the world of internet communication. The social responsibility of library-information work now is more prominent than in the entire history of librarianship so far.

The new role of librarians in the future will also require fundamental changes in the approach to educating library-information experts. In a situation when the user has the possibility of independent access to distant databases, both bibliographic and factographic and full-text databases, the essential mediating role of librarians is necessary mostly in complex searches, selection and assessment of retrieved data. The standard form of library work will increasingly turn into the content analysis of information and analytic processing of electronic documents that include text, image, sound and video recording.

Contemporary computer networks and systems are often overloaded with ephemeral information of little value. They contain more and more information of commercial and entertaining character. It is the task of the libraries to select really valuable records of knowledge and experience from that infinite sea and preserve them for the future generations. In this process, information analysis as an intrasystemic library function and axiological-orientational social function are not only technical and organisational tasks, but they demand a broader, sociologically and axiologically founded approach to all user categories.

Although one can justly say that information literacy is relevant to the entire user population in contemporary libraries, this process is of special importance to those users whose professional status depends on the quality and speed of retrieved information, like students or scholars. Taking the earlier quoted definition of information literacy as a point of departure, we list several essential tasks of their training for an active use of library resources in the electronic environment: identification of information needs, selection of relevant information, formulation of search queries, distinction between popular and scientific sources of information, distinction between primary and secondary information resources, using Boolean operators in searches, selection of strategies for database search, understanding the problem of information overload, critical use of information resources, organisation and transmission of retrieved information, correct citation of used sources and copyright observance on the internet, readiness for lifelong learning.

\section{Information Literacy in Serbia}

Accession to the European Union has been defined as Serbia's most important strategic goal, for the achievement of which it is necessary that individuals, the civil sector and the state administration should work in harmony. The way to the EU is seen as the way to a more modern society of stable democracy and developed economy, and the political and economic demands stipulated by the $\mathrm{EU}$ as the prerequisites of individual development and responsibility, with a simultaneous expansion of European space of peace and democracy.

The European Union has set a goal to itself that it should create the circumstances for economic development based on the production of knowledge and the rise of information society, which is described as a society where anybody can create, access, use and share information and knowledge and which enables individuals, communities and nations to realise their full potential and enhance the quality of their lives in a sustainable way. In principle, instead of the three recent sectors, agricultural, industrial and service, information society has a new one - the information sector, which comprises a wide array of knowledge and professions, from scholarship to invention, via information and communications distribution, information processing and transaction management, through computer and telecommunications equipment and programmes, broker and insurance business 
to the functioning of the government and parliament. These components of contemporary information economy clearly stand out: information production (scientific research and development, education, creative endeavour), information distribution (publishing, librarianship, television), direction and management of information transactions (in the fields of telecommunications, banking, brokerage), development of information technologies, means of support (buildings, maintenance), and this economy has given rise to a new typology of information employees: creative workers in the IT field (scientists, engineers, designers, programmers, analysts...), employees in maintenance and data processing (system administrators, database administrators, operators and other staff in computer laboratories), professionals in the domain of information collecting, processing and disseminating (instructors, consultants, librarians), and the manipulants, who directly connect the users to information (postal and bank clerks, book-keepers, employees in holdings circulation of libraries).

After two unsuccessful attempts at drafting the national strategy of information society development, in 1997 and 2002, the Ministry of Science and Technology of the Republic of Serbia adopted a document with the same title in October 2006. Written in the circumstances of relatively stable economic growth and increased foreign investment, this strategy did not envisage the latest world economic crisis, the slackening of IT markets in Serbia beginning in autumn 2008, and the increasingly more obvious consequences of industrial underdevelopment, high unemployment rate and insufficient investment in research and development. Even not taking that into account, the author of the National Strategy of Information Society Development failed to demonstrate a visionary spirit and to assign libraries a more responsible place in the overall process of social informatisation. In the text of the strategy libraries are mentioned twice in the context of digitisation (digital libraries, digital archives / libraries), twice in the catalogue of the institutions that should have broadband internet connections, and once in the context of developing the government-tocitizen public services (public libraries). Due to the essence of their social roles, libraries are not mentioned regarding the legislative framework, national information infrastructure and $e$-education, and by doing so the adopted text of the Strategy is sending a message that information society is a technical rather than a social category. It does not have in mind the essence of human communication with recorded knowledge, and it does not treat lifelong learning as a precisely developed concept. Finally, the text of the Strategy would offer less reason to worry if it had not been preceded by the Higher Education Act disastrous to libraries and librarians, and if an entire set of acts on culture, and the future library law as well, were not to draw on it.

The integral library-information system of the Republic of Serbia consists of: the national and central libraries (National Library of Serbia in Belgrade and Matica Srpska Library in Novi Sad), university libraries (Svetozar Marković University Library in Belgrade, Nikola Tesla University Library in Niš, Univeristy Library in Kragujevac, Central University Library in Novi Sad and University Library in Novi Pazar), then the Serbian Academy od Sciences and Arts Library, Serbian Patriarchate Library and Yugoslav Army Central Library, a network of public libraries and networks of highereducation, school and special libraries. Military and religious libraries are part of this system, but only to a certain extent.

It is interesting to find out that even in such a unfavourable general framework the libraries have sought their own ways of development. After in 2002 the National Digitisation Centre was established (as a project initiative, not as a state institution), it attracted libraries and made them almost the most important partner on the project. The National Library of Serbia (NBS) has been developing a digital library since 2003, and since 2008 it has been a member of the World Digital Library, with more than a million digitised documents. A number of public libraries, like the libraries in Kruševac, Čačak and Sombor, in cooperation with the local archives, have initiated projects of local cultural heritage digitisation, and the Svetozar Marković University Library in Belgrade is the carrier of the Ph.D. and M.A. thesis digitisation project. There have been some praiseworthy 
examples of cooperation like the one between the National Library of Serbia and the Vladislav Petković Dis Čačak City Library, on the basis of which in January 2010, the famous interwar edition of children's literature, "The Golden Book", digitised in Čačak, was donated to the Digital NBS.

However, it is hard to tell how much the digital objects at our disposal are actually being used. There has been no research to cover this topic, and the familiarity with the general situation makes one conclude that they are being treated rather as a trend, as a quality of modernisation or status symbols, than as something that improves the quality of life and satisfies the citizens' real needs. We know from experience that Serbian secondary school students have classes of information literacy, but that they enrol in the first year of college with only a vague conception of the possibilities of searching library materials; in practice we can even see senior students who have difficulty in relating the use of libraries and their grades; conversations with students reveal that they most often prepare for examinations with the aid of scripts, lecture notes and books, and that they come to classes unprepared without experiencing them as a chance for interactive work and exchange of opinions; it is hard not to notice that students in large university centres spend much time in social networking actions, but that they scarcely use electronic resources for learning. However, we also know that the all-pervasive crisis of reading has taken its toll on Serbia as well, and that society is not confronting it with organised actions; we are aware that these libraries do not engage in long-term, systematic training of students in library resource use, and that there is a real chasm between students' information skills and the possibility to, for example, use over 30,000 electronic journals at the University Library; we trust that efficient work of reference librarians would be a quality step forward...

The situation is also unenviable when it comes to public libraries: the percentage of population with the membership in public libraries of Serbia in 2008 is $6,36 \%(8,06 \%$ in Vojvodina and 5,72\% in Serbia proper), and library holdings turnover was only 0,56 (even less in Vojvodina - 0,46, and in Serbia proper - 062). One of the most serious problems of the public library network is an insufficient volume of material acquisition. The cultural policy of the current Ministry of Culture stipulates the purchase of publications from the present production as one of the three strategic actions in the library-information field. The Belgrade Public Library, as the largest public library in Serbia, is the leader in the programmes of information literacy and web 2.0 technology introduction to library work, but its level of activity is not typical of Serbian circumstances. According to a 2007 poll, the Belgrade region is 7 times more developed than the Serbian south, but the difference is increasing having in view the fact that the local self-management in the capital is decidedly intent on strengthening the public library system.

Problems in the operation of school libraries can be traced not so much in the number of books (an average 14,7 per student) as in their inappropriate subject-matter $(57 \%$ of reading intended for first-language lessons), in a conspicuously high number of libraries not having the essential information aids, and in an unstable structure, a constant fluctuation of about 1,200 employees out of whom only one half actually occupy a librarian's position. The Zemun High School Electronic Library stands out as an exception, with a formed repository of learning objectives grouped in: instruction material organised by subject boards, psychological-pedagogical materials, school librarians' database, students' work, video and audio recordings defined by subject, and the electronic books. The learning objectives (an element of knowledge or an entire lesson) were produced by the teachers and students or by teams of teachers and students in our school and in others. Part of the repository consists of links to select learning objectives in other reference institutions.

Through the problems listed looms the need to professionalise the library activity in Serbia. Although the first state-appointed librarian in this country was employed as early as 1853, librarianship in Serbia was qualified as a scientific discipline only in 2007. The Ministry of Science and Technological Development did that in the passing of the University Act, solving the paradox according to which there was university education in librarianship and 
library information science, scientificresearch papers were written and academic titles conferred, but the discipline itself was not included in the group of sciences studied in our institutions of higher education. The problem of professionalisation of the library activity on the one hand and the problem of verifying the scientific librarian community in Serbia on the other, imply a dialogue on the position of graduate librarians and of those that have acquired that title at work, on the manner of passing the licensing examinations and promotions, assessment of scientific achievement on the part of library employees, stimulation of young librarians to scientific commitment, recruitment of scholars for solving problems of the trade, work in trade organisations, professional and scientific periodicals, awards, evaluation methods, citation, consulting... The Library Law, whose draft is under way, should mark a turning point and clearly define the master's level as a necessary prerequisite for performing professional librarians' tasks, and the terms under which other educational profiles are employed at libraries.

\section{Conclusion}

The absence of a clear and consequent national strategy in the development of information literacy does not mean that information literacy in Serbia is not developing, but that it is developing sporadically and not efficiently enough. Instead of the system working as a whole, individual actions and initiatives are taken that are, from their own perspectives, trying to bridge the gap between the demands of the global information age and the situation in the field. The coordination of initiatives, ideas and strategies would bring about more focus and much quicker results in terms of raising the percentage of informationally literate population and their capacity for lifelong learning.

The current position of libraries and librarianship in Serbia reflects all childhood diseases of the information literacy concept. Although national strategies have not properly capitalized on their true potential, libraries in Serbia now operate in a society that is demonstrating an increased level of strategic orientation to scientific development and trying to make more investment in scientific research, education and culture. Library initiatives, project organisation, participation in international projects, work in international associations and professional education imply that the librarians, with all objective obstacles, understand information literacy as their regular duty. The future efforts of libraries and librarians on redesigning their own mission must be clearly directed towards a noticeable and measurable contribution to the well-being of the community in which they work.

\section{REFERENCES}

1. ШЕКУЛАРАЦ, В., Мрежа јавних библиотека Србије у периоду 2000 2008. година,

http://www.nb.rs/view_file.php?file_id=2 623, (25.03.2010).

2. ВУКОТИЋ, Б., Особље у мрежи јавних библиотека у Србији у 2005. години, http://www.nb.rs/view_file.php? file_id=1897, (25.03.2010).

3. ŠPIRANEC S., M. BANEK ZORICA, Informacijska pismenost - teorijski okvir i polazišta, Zavod za informacijske studije, Zagreb, 2008.

4. ФИЛИПИ-МАТУТИНОВИЋ, С., које су перспективе високошколских библиотека у ери информација? Инфотека бр. 32005.

www.unilib.bg.ac.yu/zajednica01/izdanja /infoteka/br3_2005/INFOTEKA_VI_3_S eptembar2 005_177-195.pdf(13.05.2009).

5. СТОКИЋ СИМОНЧИЋ, Г., Best Practice у 22 приче: комуникација, култура организације, односи библиотека с јавношћу, Градска библиотека, Панчево, 2009.

6. ВРАНЕШ, А., Г. МАРКОВИЋ, Љ., АЛЕКСАНДЕР (eds), Информациона писменост и доживотно образовање, Филолошки факултет, Библиотекарско друштво Србије, Београд, 2008.

7. ДЕЛОР, Ж., Образовање: скривена ризница, Београд, 1996.

8. Strategiju razvoja informacionog društva u Republici Srbiji, 
http://www.mtid.gov.rs/upload/document s/propisi/strategije/Strategija i akcioni plan za razvoj informacionog drustva.pdf (25. 02. 2010).

9. Стратегија научног и технолошког развоја Републике Србије у периоду од 2010. до 2015. године http://www.nauka.gov.rs/cir/images/storie s/vesti/strategija/strategija_naucnog_i_teh noloskog_razvoja_srbije_u_periodu_od_2 010_do_2015_godine.pdf (25.02.2010).

10. Stability Pact - eSEEurope Initiative eSEEurope Agenda for the Development of the Information Society a cooperative effort to implement the Information Societyin South Eastern Europe http://www.bos.rs/cepit/idrustvo/id/agend a.pdf (25. 02. 2010).

11. СТОКИЋ СИМОНЧИЋ, Г., Ж. ВУЧКОВИЋ, Управљање библиотекама у добу знања, Градска библиотека, Панчево, 2003.

12. SCHEIRER, B., The Changing Role of the Teacher-Librarian in the Twentyfirst Century, http://www.usask.ca/ education/coursework/802papers/scheirer/sc heirer.htm (25.02.2010).
13. VUČKOVIĆ, Ž., Estetika i kultura medija, Cekom books, Novi Sad, 2007.

14. BALLANTYNE, P., Accessing and Disseminating Scientific Information in South Eastern Europe, UNESCO, Regional Bureau for Science in Europe, 2005.

15. PAGE T., G. THORSTEINSSON, A. NICULESCU, Management of Knowledge in a Problem Based Learning Environment, in SIC - vol. 18 , no. $3 / 2009$.

16. BANCIU, D., e-Romania - A Citizens' Gateway towards Public Information, in SIC vol. 18, No.3/2009.

17. THENG, Y.- L, S. FOO, D. GOH, J.-C. NA, (eds.) Handbook of Research on Digital Libraries: Design, Development and Impact, Information Science Reference, Hershey, 2009. 